\title{
PENGARUH PEMBIAYAAN MUDHARABAH TERHADAP PENINGKATAN KEBERHASILAN USAHA NASABAH PADA PT. BPR SYARIAH HAJI MISKIN: PERSPEKTI NASABAH
}

\author{
Rici Novika \\ BPR Syariah Haji Miskin Jl. Jendral Sudirman No. 94 \\ Lima Kaum Batusangkar \\ e-mail: novika.rici@yahoo.com
}

\begin{abstract}
The purpose of this study was to determine the effect of Mudharabah financing on Increasing Customer Business Success at PT. Sharia BPR Haji Miskin: Customer Perspective. The type of research used in this study is associative research which is a research that aims to determine the effect or relationship between two variables. The population in this study were all customers who carried out mudharabah financing at PT. BPR Syariah Haji Miskin. The instrument of this research is a questionnaire. Then data processing is done by SPSS 22.0 with data analysis techniques using simple linear regression. As for the results of the analysis, mudharabah financing has a positive effect on the increase in customer business success at PT. BPR Syariah Haji Miskin. This can be seen from the results of the persial test t test that is the significance value of mudharabah financing is $0.023 \%$ small from the $0.05 \%$ significance value which means mudharabah financing has an effect on increasing the success of the customer's business. From the result of 20.25\% mudaraba against the increase in the success of the customer's business is equal while the remaining $79.75 \%$ is influenced by other vaiable that is not examined.
\end{abstract}

Keywords: Mudharabah Financing, Increasing Customer Business Success

\section{PENDAHULUAN}

Mudharabah adalah suatu transaksi pembiayaan perbankan Islam yang dilakukan oleh para pihak yang berdasarkan kepercayaan. (Langit, 2013,p.2) Mudharabah merupakan kontrak yang melibatkan antara dua kelompok yaitu pemilik modal (investor) yang mempercayakan modalnya kepada pengelola (mudharib) untuk digunakan dalam aktivitas perdagangan. Pengelola (mudharib) bebas menggunakan modal tersebut dengan bentuk bisnis yang dijalankan, masa usahanya dan tempat mudharib menjalankan bisnis/usahanya (Langit, 2013,p.2)

Modal sangatlah penting dalam kegiatan usaha, bahkan dalam meningkatkan kegiatan produktifitas dan sebagai alat ukur untuk mengukur tingkat pendapatan. Income (pendapatan) dalam ilmu ekonomi teoritis adalah hasil yang diterima atau didapat, baik berupa uang maupun lainnya atas penggunaan kekayaan atau jasa manusia. Tersedianya modal yang cukup akan 
memungkinkan suatu badan usaha untuk dapat mempertahankan eksistensinya dan dapat menjalankan kegiataan sehari-hari dengan lancar (Langit, 2013,p.2)

Menurut Imron,M (2008,p.119) Faktor-faktor penentu keberhasilan usaha terdiri dari: 1. Modal merupakan besarnya rata-rata modal kerja yang dikeluarkan setiap hari untuk membeli barang dagangan (kulaan) atau bahan-bahan mentah untuk membuat barang dagangan. Definisi modal juga dapat mengacu pada modal yang digunakan sebagai investasi untuk menjalankan kegiatan usaha. Secara logis dapat dikemukakan bahwa semakin tinggi modal kerja yang dikeluarkan oleh pedagang maka semakin tinggi pula laba bersih yang dihasilkan (ceteris paribus dengan asumsi semua barang dapat terjual). 2. Jumlah tenaga kerja adalah banyaknya orang yang melakukan bekerja di usaha tersebut. Tenaga kerja merupakan faktor produksi yang menunjang kelangsungan hidup perusahaan, karena produktivitas usaha sangat ditentukan oleh tenaga kerja yang ada. 3. Tingkat pendidikan adalah pendidikan terakhir yang ditempuh oleh pemilik usaha tersebut. 4. Pengalaman variabel ini diukur dari lama waktu pemilik warung sudah menjalankan usahanya sampai saat melakukan pengisian kuesioner.
Pemilik usaha selain sebagai pemimpin juga dapat bertindak sebagai tenaga teknis administrasi. Pengalaman pedagang sangat penting karena dalam setiap mengelola usahanya mereka harus menguasai tata cara pengelolaan usahanya termasuk pengelolaan pelanggan. 5 . Lama jam kerja merupakan jam buka usaha. Semakin lama jam kerja atau jam buka usaha maka akan semakin besar pula potensi penghasilan dan laba yang diperoleh (Imron, $\mathrm{M}$, 2008,p.119)

Pespektif berasal dari bahasa itali "prosepettiva" yang berarti gambaran atau pandangan (Suparyono, 1981,p.7). Untuk melihat tingkat keberhasilan usaha nasabah dengan pemberian pembiayaan mudharabah oleh PT. BPR Haji Miskin maka diperlukan perspektif nasabah, karena tingkat keberhasilan usaha nasabah yang dimaksud adalah berdasarkan tinjauan lapangan dan wawancara langsung terhadap nasabah. Mengingat pembiayaan mudharabah ini sangat beresiko terhadap tingkat pengembalian kembali kawajiban nasabah serta jumlah pembayaan yang diberikan guna meningkatkan keberhasilan usaha nasabah. Tidak dapat dipungkiri bahwa tingkat keberhasilan usaha nasabah ini memang berhasil atau tidak tentunya harus dilihat secara ilmiah. 
KAJ IAN TEORITIS

\section{Bank Syariah}

Bank Syariah adalah lembaga intermediasi dan penyedia jasa keuangan yang bekerja berdasarkan etika dan sistem nilai Islam, khususnya yang bebas dari bunga (riba), bebas dari kegiatan spekulatif yang non produktif, bebas dari hal-hal yang tidak jelas (gharar), berprinsip keadilan dan hanya membiayai kegiatan usaha yang halal (Wibowo dan Sunarto, N.Y,p.116). Keberadaan bank syariah cenderung lebih disebabkan adanya keinginan masyarakat muslim yang menghendaki adanya pelaksanaan transaksi perbankan atau kegiatan ekonomi secara umum yang sejalan dengan nilai dan prinsip syariah. Perbankan syariah adalah lembaga keuangan atau perbankan yang operasional dan produknya dikembangkan berdasarkan kepada Al-Qur'an dan Hadits Rasulullah SAW. Bank syariah adalah bank yang mekanisme kerjanya menggunakan mekanisme bagi hasil. Bank syariah menggunakan prinsip-prinsip syariah yang tentunya sangat berbeda dengan prinsip yang dianut oleh bank konvensional.

\section{Tujuan dan Manfaat Pembiayaan}

Tujuan pembiayaan berdasarkan prinsip syari'ah adalah untuk meningkatkan kesempatan kerja dan kesejahteraan ekonomi sesuai dengan nilai-nilai Islam. Pembiayaan tersebut harus dapat dinikmati oleh sebanyakbanyaknya pengusaha yang bergerak dibidang industri, pertanian, dan perdagangan untuk menunjang kesempatan kerja dan menunjang produksi dan distribusi barang-barang dan jasa-jasa dalam rangka memenuhi kebutuhan dalam negeri maupun ekspor (Muhammad ,2005, p. 263).

Ada beberapa manfaat pemberian pembiayaan oleh lembaga keuangan syariah kepada nasabah, diantaranya adalah sebagai berikut:

a. Untuk meningkatkan usaha nasabah, pembiayaan yang diberikan oleh lembaga keuangan syariah kepada nasabah yaitu dalam rangka perluasan volume usaha, baik dalam bentuk pembelian bahan baku, pengadaan mesin dan peralatan dapat membantu nasabah untuk meningkatkan volume usahanya.

b. Mengurangi tingkat pengangguran, dengan adanya pembiayaan dari lembaga keuangan syariah maka masyarakat yang tidak bekerja dapat membuka lapangan pekerjaan atau usaha sendiri 
sehingga tidak menjadi pengangguran.

c. Nasabah dapat memilih berbagai jenis pembiayaan berdasarkan akad dan kebutuhan nasabah sesuai dengan prinsip syariah.

d. Jangka waktu pembiayaan disesuaikan dengan kemampuan nasabah

e. Lembaga keuangan syariah akan menjadi tulang punggung bagi usaha kecil menengah (UKM) untuk bisa bertransformasi menjadi perusahaan yang memasuki sektor formal tanpa beban bunga (Ismail, 2011, p.110)

\section{Pembiayaan Mudharabah}

Mudharabah disebut juga dengan qirad atau muqaradah yang berarti al-Qat'u (pertolongan) karena pemilik memotong sebagian hartanya untuk diperdagangkan oleh pengusaha dan memperoleh sebahagian keuntungan (Iska,S, 2012,p.185)

Menurut Wibowo dan Sunarto (N.Y,p.116) Mudharabah merupakan akad bagi hasil ketika pemilik dana, bisa disebut shahibul mal/rabbul mal, menyediakan modal 100 persen kepada pengusaha sebagai pengelola, biasa disebut mudharib. Untuk melakukan aktivitas produktif dengan syarat bahwa keuntungan yang dihasilkan akan dibagi di antara mereka menurut kesepakatan yang ditentukan sebelumnya dalam akad (yang besarnya juga dipenaruhi oleh kekuatan pasar).

Secara khusus mudharabah adalah akad kerja sama usaha antara dua pihak yang mana pihak pertama (shahibul al-mal) menyediakan seluruh (100\%) modal, sedangkan pihak lain menjadi pengelola (mudharib).keuntungan usaha secara mudharabah dibagi menurut kesepakatan yang dinyatakan dalam kontrak, tetapi kerugian ditanggung oleh pemilik modal selagi ia bukan akibat kelalaian sipengelola. Seandainya kerugian itu disengaja atau sebab kecurangan atau kelalaian si pengelola harus bertanggung jawab atas kerugian tersebut (Iska,S, 2012,p.186)

Akad mudharabah merupakan akad transaksi berbasis investasi atau penanaman modal pada satu kegiatan usaha tertantu. Bank dan nasabah bersepakat menjalin kerja sama pada suatu usaha/ proyek dimana bank menyediakan modal/ dana, sedangkan nasabah menyediakan keahlihan/ keterampilan untuk mengerjakan proyek tersebut (Indonesia,B.I, 2014,p.214)

\section{Indikator Pembiayaan Mudharabah}

Menurut Fadila,N (2015,p.66) tentang kinerja perbankan syariah relatif baik ditandai dengan pertumbuhan yang tinggi pada 
sejumlah indikator utama pembiayaan mudharabah adalah antara lain

1) Data nabasah

Data nasabah adalah identitas yang dimiliki oleh nasabah yang harus diketahui oleh pihak perbankan dalam melakukan pembiayaan mudharabah

2) Kemampuan angsuran

Kemampuan angsuran adalah kesanggupan nasabah dalam mengembalikan angsurannya

3) Hasil usaha yang dijalankan Hasil usaha yang dijalankan adalah suatu gambaran usaha yang lakukan oleh nasabah betul-betul nyata/ ada.

4) Nisbah pembiayaan

Nisbah pembiayaan adalah keuntungan proporsi bagi hasil antara nasabah dan bank syariah.

5) Distribusi pembagian hasil

Distribusi pembagian hasil menurut KBBI (Kamus Besar Bahasa Indonesia adalah pennyaluran (pembagian, pengiriman) kepada beberapa orang atau ke beberapa tempat

6) Modal

Pengertian modal menurut KBBI (Kamus Besar Bahasa Indonesia adalah uang yang digunakan sebagai pokok (induk) untuk berdagang; harta benda (uang, barang) yang bisa digunakan dalam menghasilkan sesuatu yang mampu menambah kekayaan dan sebagainya.

4. Indikator Peningkatan Keberhasilan Usaha Nasabah

Dalam penelitian ini menggunakan indikator keberhasilan dari Pemungkas, P (2104,p.20) yaitu terdiri dari :

1) Meningkatnya omzet

Omzet penjualan yang terus mengalami peningkatan tertentu menunjukkan bahwa terjadi peningkatan dalam usaha. Usaha yang tidak berkembang atau stagnan tidak akan mungkin mengalami peningkatan penjualan atau omzet. omzet penjualan adalah keseluruhan jumlah pendapatan yang didapat dari hasil penjualan suatu barang atau jasa dalam kurun waktu tertentu.

2) Meningkatnya aset

Peningkatan pada aset usaha merupakan salah satu bentuk usaha yang kinerjanya mengalami peningkatan. Dalam suatu usaha, aset mempunyai fungsi yang penting untuk menunjang kegiatan produksi di mana merupakan sumber penghasilan yang akan digunakan untuk masa sekarang dan masa yang akan 
datang. Aset yang dimiliki para UMKM yang menerima pembiayaan mudharabah ratarata bertambah setelah mereka mendapatkan tambahan modal dari PT. BPR Syariah Haji Miskin. sebagainya yang diharapkan dapat meningkatkan kinerja usaha mereka. menyatakan bahwa aset yang dimiliki bertambah setelah mendapatkan tambahan modal dari pembiayaan mudharabah (Musdiana N.R, 2015,p.33)

3) Pendapatan Usaha meningkat Pendapatan yang diterima oleh nasabah penerima pembiayaan mudharabah sebagian besar mengalami peningkatan. Pendapatan usaha terkait dengan laba atau rugi yaitu jika terjadi kelebihan pendapatan atau surplus dari kegiatan usaha yang diperoleh dari selisih antara pendapatan (revenue) dengan beban terkait dalam suatu periode tertentu, maka menghasilkan laba. Sebaliknya jika terjadi kekurangan pendapatan atau defisit dari kegiatan usaha yang diperoleh dari selisih antara pendapatan (revenue) dengan beban terkait dalam suatu periode tertentu, maka usaha tersebut mengalami rugi.
4) Meningkatnya volume Penjualan

Volume penjualan merupakan jumlah unit produk yang mampu dijual perusahaan. Semakin tinggi volume penjualan maka perusahaan tersebut memiliki strategi pemasaran yang baik. Jadi volume penjualan adalah hasil dari penjualan yang diukur menggunakan satuan.

5) Stabilitas usaha

Stabilitas usaha yaitu kemampuan perusahaan untuk melakukan usahanya dengan stabil, yang diukur dengan mempertimbangkan

kemampuan perusahaan untuk membayar kewajiban atas hutang-hutangnya tepat pada waktunya serta kemampuan menjalankan usahanya secara berkelanjutan tanpa mengalami hambatan atau krisis keuangan. Stabilitas usaha dapat diartikan sebagai kemampuan suatu usaha dalam mempertahankan usahanya agar dapat tetap berjalan dengan baik secara berkelanjutan (continue) sehingga dapat mencapai peningkatan dalam usahanya. 
5. Kajian

Penelitian

Relevan

Dalam penelitian Suryati (2012) mengatakan bahwa pemberian pembiayaan mudharabah terhadap perkembangan usaha nasabah memiliki pengaruh positif dan signifikan dengan nilai koefisien jalur (R) sebesar 0,717; terdapat pengaruh positif dan signifikan antara perkembangan usaha terhadap peningkatan pendapatan nasabah dengan nilai $\mathrm{R}$ sebesar 0,535 ; terdapat pengaruh pemberian pembiayaan mudharabah terhadap peningkatan pendapatan nasabah mudharabah melalui perkembangan usaha. Besarnya pengaruh tidak langsung pembiayaan mudharabah terhadap peningkatan pendapatan nasabah adalah 0,383 .

Selanjutnya berdasarkan hasil penelitian Langit (2013) serta telah dilakukan perhitungan dari analisis regresi dapat diperoleh koefisien korelasi $\mathrm{R}=0,948$ yang berarti terdapat pengaruh yang kuat pada variabel $\mathrm{X}$ terhadap variabel $\mathrm{Y}$, dengan determinasi sebesar 89,8 \%. Hasil perhitungan uji $t$, bahwa thitung $(18,524)>$ dari ttable $(141,138)$ sedangkan signifikansi $(0,000)<$ dari alpha pada taraf $5 \%$ atau 0,05 . Sehingga Ha diterima dan Ho ditolak. Sehingga dapat disimpulkan bahwa secara parsial pembiayaan mudharabah berpengaruh positif terhadap peningkatan pendapatan nasabah. Menurut Sahany (2015) mengatakan bahwa pembiayaan murabahah dan mudharabah mempunyai pengaruh positif terhadap perkembangan UKM nasabah BMT El Syifa

\section{METODE PENELTIIAN}

\section{Jenis Penelitian}

Dalam penelitian ini pendekatan yang digunakan yakni pendekatan Kuantitatif. Pendekatan ini lebih didasarkan pada data yang dapat dihitung untuk menghasilkan penaksiran kuantitatif yang kokoh. Pendekatan kuantitatif merupakan pendekatan penelitian yang bekerjasama dengan angka, datanya berwujud bilangan, dianalisis dengan menggunakan statistik untuk menjawab rumusan masalah penelitian yang bersifat spesifik dan untuk melakukan prediksi bahwa suatu variabel tertentu dapat mempengaruhi variabel lain. Penelitian ini dilakukan di PT. BPRS Haji Miskin Pandai Sikek dengan penelitian pengaruh perspektif nasabah tentang pembiayaan mudharabah terhadap peningkatan keberhasilan usaha nasabah pada PT. BPR Syariah Haji Miskin

\section{Instrumen Penelitian}

Instrumen (alat pengumpul data) dalam penelitian ini adalah angket 
pembiayaan mudharabah dan angket tingkat keberhasilan usaha nasabah. Dalam penelitian ini langkah yang digunakan untuk memperoleh informasi dari reponden adalah berbentuk angket. Angket yang gunakan untuk melihat pembiayaan mudharabah dan tingkat keberhasilan usaha nasabah. Angket tingkat keberhasilan usaha nasabah mengunakan angket yang dikembangkan oleh (Sahany, 2015) yang sudah valid dan reliable, sementara angket yang digunakan untuk melihat pembiayaan mudharabah disusun sesuai dengan langkah-langkahnya. Angket yang akan diberikan adalah angket tertutup, dimana semua pertanyaan yang diajukan sudah ada pilihan jawabannya.

\section{Teknik Pengumpulan Data}

Sumber data yang digunakan dalam penelitian ini merupakan subjek dari mana data tersebut diperoleh. Dalam penelitian ini menggunakan data primer. Data primer adalah data atau informasi yang diperoleh langsung sumbernya. Data primer berupa data yang diperoleh dalam bentuk opini seseorang secara individu maupun kelompok dan hasil observasi (Istijanto, 2009, p.64). Beberapa teknik dalam mengumpul data primer adalah dengan cara sebagai berikut: Observasi, wawancara, kuisioner

\section{Teknik Analisis Data}

Analisis data merupakan kegiatan setelah data dari seluruh responden atau sumber data lain terkumpul (Sugiyono, 2012: 207). Dalam penelitian ini memakai hipotesis asosiatif, yaitu dugaan terhadap ada tidaknya hubungan secara signifikan antara dua variabel atau lebih. Dalam penelitian ini menentukan hubungan pembiayaan mudharabah (X), terhadap peningkatan keberhasilan usaha nasabah (Y).

\section{HASIL PENELITIAN dan} PEMBAHASAN

\section{Hasil Penelitian}

a. Uji Regresi Linear Sederhana Untuk melihat uji $\mathrm{T}$ maka dapat dirumuskan terlebih dahulu hipotesisnya agar memudahkan dalam melakukan analisis dan pengambilan keputusan. Adapun hipotesisnya adalah sebagai berikut:

H1 : Terdapat pengaruh antara variabel pembiayaan mudharabah (X) Peningkatan Keberhasilan Usaha Nasabah (Y)

Hasil uji T Test Parsial

Pengaruh pengaruh Pembiayaan Mudharabah terhadap peningkatan keberhasilan usaha nasabah 


\section{Coefficients $^{\mathrm{a}}$}

\section{Coefficients $^{\mathrm{a}}$}

\begin{tabular}{|c|c|c|c|c|c|c|}
\hline \multirow{2}{*}{$\begin{array}{l}\text { Mod } \\
\text { el }\end{array}$} & \multicolumn{2}{|c|}{$\begin{array}{c}\text { Unstandardized } \\
\text { Coefficients }\end{array}$} & \multicolumn{2}{|c|}{$\begin{array}{l}\text { Standardized } \\
\text { Coefficients }\end{array}$} & \multirow[b]{2}{*}{$\mathrm{t}$} & \multirow[b]{2}{*}{ Sig. } \\
\hline & B & Std. Error & \multicolumn{2}{|c|}{ Beta } & & \\
\hline \multicolumn{2}{|c|}{$\begin{array}{l}1 \text { (Constant } \\
\text { ) }\end{array}$} & 48.850 & 6.447 & & $7 \cdot 578$ & .000 \\
\hline $\mathrm{x}$ & & -.552 & .227 & -.445 & -2.433 & .023 \\
\hline
\end{tabular}

.a. Dependent Variable: y

Sumber: data diolah (SPSS 22,0

Dari tabel di atas dapat diketahui bahwa nilai signifikansi untuk variabel pembiayaan mudharabah adalah 0,023 lebih kecil dari 0,05 atau thitung 7,578 lebih besar dari ttabel 2,0930. Hal ini dapat disimpulkan bahwa H1 diterima yaitu variabel Pembiayaan mudharabah berpengaruh terhadap peningkatan keberhasilan usaha nasabah b. Uji Koefisien Determinasi
Untuk melihat proporsi pengaruh yang diberikan oleh variabel Pembiayaan Mudharabah Terhadap Peningkatan Keberhasilan Usaha Nasabah maka dapat dilihat dati tabel model summary

Hasil uji koefisien determinasi Variabel Pembiayaan Mudharabah Terhadap Peningkatan Keberhasilan Nasabah

\begin{tabular}{|l|c|r|r|r|}
\hline $\begin{array}{l}\text { Mode } \\
\mathrm{l}\end{array}$ & $\mathrm{R}$ & R Square & $\begin{array}{c}\text { Adjusted R } \\
\text { Square }\end{array}$ & $\begin{array}{c}\text { Std. Error of the } \\
\text { Estimate }\end{array}$ \\
\hline 1 & $.445^{\mathrm{a}}$ & .198 & .164 & 6.78262 \\
\hline
\end{tabular}

Sumber: data diolah (SPSS 22.0)

Dari tabel diatas maka dapat sebesar 0,445 hal ini menunjukan diketahui bahwa nilai $R$ adalah bahwa variabel Pembiayaan 
Mudharabah memberikan pengaruh terhadap Peningkatan Keberhasilan usaha nasabah adalah sebesar 20,25\% sedangkan untuk 79,75\% dipengaruhi oleh variabel lain yang tidak diteliti.

\section{Pembahasan}

Berdasarkan hasil penelitian di atas maka dapat dibahas sebagai berikut: Pengaruh pembiayaan mudharabah terhadap peningkatan keberhasilan usaha nasabah. Berdasarkan pengujian dari hasil penelitian di atas dapat diketahui bahwa pembiayaan mudharabah berpengaruh terhadap peningkatan keberhasilan usaha nasabah. Hal ini berarti setiap penambahan pembiayaan mudharabah maka mempengaruhi peningkatan keberhasilan usaha nasabah. Hal ini dapat dilihat dari hasil pengujian $t$ tes parsial yaitu nilai signifikansi pembiayaan mudharabah adalah sebesar 0,023 kecil dari nilai signifikansi 0,05 yang artinya pembiayaan mudharabah berpengaruh terhadap peningkatan keberhasilan usaha nasabah. Dari hasil model summary dapat dilihat bahwa pengaruh yang diberikan oleh pembiayaan mudharabah terhadap peningkatan keberhasilan usaha nasabah adalah sebsar 20,25\% sedangkan sisanya sebesar 79,75\% dipengaruhi oleh variabel lain yang tidak diteliti.
Hasil ini didukung oleh penelitian terdahulu yang dilakukan oleh Suryati (2012), mengatakan bahwa pemberian pembiayaan mudharabah terhadap perkembangan usaha nasabah memiliki pengaruh positif dan signifikan dengan nilai koefisien jalur (R) sebesar 0,717; terdapat pengaruh positif dan signifikan antara perkembangan usaha terhadap peningkatan pendapatan nasabah dengan nilai R sebesar o,535; terdapat pengaruh pemberian pembiayaan mudharabah terhadap peningkatan pendapatan nasabah mudharabah melalui perkembangan usaha. Besarnya pengaruh tidak langsung pembiayaan mudharabah terhadap peningkatan pendapatan nasabah adalah 0,383 .

Sejalan juga dengan pendapat Langit (2013), serta telah dilakukan perhitungan dari analisis regresi dapat diperoleh koefisien korelasi $\mathrm{R}=0,948$ yang berarti terdapat pengaruh yang kuat pada variabel $\mathrm{X}$ terhadap variabel $\mathrm{Y}$, dengan determinasi sebesar 89,8 \%. Hasil perhitungan uji t, bahwa thitung $(18,524)>$ dari ttable $(141,138)$ sedangkan signifikansi $(0,000)<$ dari alpha pada taraf $5 \%$ atau 0,05. Sehingga Ha diterima dan Ho ditolak. Sehingga dapat disimpulkan bahwa secara parsial pembiayaan mudharabah berpengaruh positif terhadap peningkatan pendapatan nasabah. dilanjutkan oleh Sahany 
(2015) mengatakan bahwa dapat dinyatakan bahwa indikator pembiayaan murabahah dan pembiayaan mudharabah yang tinggi mudharabah mempunyai pengaruh mempengaruhi peningkatan positif terhadap perkembangan UKM keberhasilan usaha nasabah adalah nasabah BMT El Syifa.

Indikator pembiayaan indakator modal, karena modal yang akan mempengaruhi penting dalam mudharabah yang pertama adalah dilihat dari modal. Modal sangatlah penting dalam kegiatan usaha, bahkan dalam meningkatkan kegiatan produktifitas dan sebagai alat ukur untuk mengukur tingkat pendapatan. Income (pendapatan) dalam ilmu ekonomi teoritis adalah hasil yang diterima atau didapat, baik berupa uang maupun lainnya atas penggunaan kekayaan atau jasa manusia. Tersedianya modal yang cukup akan memungkinkan suatu badan usaha untuk dapat mempertahankan eksistensinya dan dapat menjalankan kegiataan seharihari dengan lancar.

Indikator

pembiayaan

mudharabah yang kedua adalah dilihat dari hasil usaha yang dijalankan. Perbankan syariah akan melihat usaha yang dijalankan oleh nasabah. Perbankan syariah akan melihat perkembangan usaha nasabah. Indikator pembiayaan mudharabah yang ketiga adalah kemampuan angsuran adalah kesanggupan nasabah dalam mengembalikan angsurannya. Berdasarkan uraian indikator pembiayaan mudharabah tersebut, menjalankan usaha. Artinya pembiayaan mudharabah berdampak pada peningkatan keberhasilan usaha nasabah. Sehingga dapat dinyatakan bahwa pembiayaan mudharabah memiliki pengaruh yang positis dan kuat terhadap peningkatan keberhasilan usaha nasabah. Hal itu juga terbukti dengan uji hipotesis statistik yang telah dilakukan dan diperoleh hasil bahwa pembiayaan mudharabah mempunyai pengaruh terhadapa peningkatan keberhasilan usaha nasabah pada PT. BPR Syariah Haji Miskin: perspektif nasabah

\section{KESIMPULAN}

Berdasarkan analisis data dan pembahasan yang sudah diuraikan menunjukkan bahwa hipotesis yang diajukan diterima dalam arti terdapat pengaruh antara variabel independen dan variable dependen. Adapun hasil analisis adalah Pembiayaan Mudharabah memiliki pengaruh yang positif terhadap Peningkatan Keberhasilan Usaha Nasabah di PT. BPR Syariah Haji Miskin Hal ini dapat dilihat dari hasil pengujian $t$ tes parsial yaitu nilai signifikansi pembiayaan mudharabah adalah 
sebesar 0,023 kecil dari nilai signifikansi 0,05 yang artinya pembiayaan mudharabah berpengaruh terhadap peningkatan keberhasilan usaha nasabah. Dari hasil model summary dapat dilihat bahwa pengaruh yang diberikan oleh pembiayaan mudharabah terhadap peningkatan keberhasilan usaha nasabah adalah sebsar 20,25\% sedangkan sisanya sebesar $79,75 \%$ dipengaruhi oleh variabel lain yang tidak diteliti.

\section{Saran}

$\begin{array}{ccr}\text { Untuk mencapai tujuan } \\ \text { pembiayaaan } & \text { Mudharabah yang }\end{array}$ diberikan oleh lembaga keuangan syariah kepada nasabah, maka pihak LKS kiranya memberikan pembiayaan tersebut kepada masyarakat yang memang memiliki usaha yang produktif dan memiliki potensi perkembangan usaha. Sehingga dengan adanya pembiayaan Mudharabah tersebut diharapkan mampu memberikan dampak yang positif terhadap peningkatan keberhasilan usaha nasabah sehingga berdampak pada peningkatan kesejahteraan nasabah. Sedangkan untuk nasabah yang menerima pembiayaan Mudharabah sekiranya juga harus berhemat dan mengkonsumsi pada tingkat yang wajar. Selain itu nasabah sejatinya harus kreatif dalam menjalankan 114 | Jurnal Tamwil, Vol. V, No. 2, Juli-Desember 2019 usaha sehingga mampu mengkreasikan bentuk usaha dalam rangka menarik pembeli sehingga meningkatkan pendapatan dan menunjang terwujudnya kesejahteraan nasabah itu sendiri.

\section{KEPUSTAKAAN ACUAN}

Fadhla, N.(2015).Analisis Pembiayaan Mudharabah dan Murabahah terhadap Laba Bank Syariah Mandiri.Jurnal Riset Akuntansi dan Bisnis.Volume 15 No. 1

Friyanto.(2013).Pembiayaan

Mudharabah, Risiko Dan Penanganannya (Studi Kasus pada Bank BTN Kantor Cabang Syariah Malang). Jurnal Manajemen Dan Kewirausahaan, Vol.15, No. 2,do10.9744/jmk.15.2.113-122 ISSN 1411-1438

Imron, M.(2008). Analisis FaktorFaktor Yang Mempengaruhi Tingkat Keberhasilan Usaha (Studi pada Warung "Nasi Kucing” di Kabupaten Jepara) Jurnal Dinamika Ekonomi \& Bisnis. Vol. 5 No. 2 Oktober 2008

Ismail.(2011).Perbankan Syariah Edisi Pertama.Jakarta.Kencana 
Istijanto, (2009). Aplikasi Praktis Riset Pemasaran, Jakarta: Gramedia Pustaka Utama

Kasmir,(2002).Bank Dan Lembaga Keuangan Lainnya, Jakarta : Raja Grafindo Persada

Langit.

P.L.(2013).Pengaruh Pembiayaan Mudharabah Terhadap Peningkatan Pendapatan Nasabah pada Bank Muamalat Indonesia Cabang Cirebon. Syekh Nurjati Cirebon

Muhammad.(2005).Manajemen Bank Syariah.Yogyakarta.UPP AMP YKPN, Muhammadiyah Malang Pres

Musdiana,N.R.(2015).Efektivitas Pembiayaan Mudharabah Dalam Meningkatkan Kinerja Umkm (Studi Kasus Pada Bmt Nurul Jannah Gresik). JEBIS Vol. 1, No. 1,

Pemungkas, R.(2014).Faktor-Faktor yang Mempengaruhi Keberhasilan Usaha Pemegang Usaha Waralaba (Studi Kasus Pada Waralaba Makanan dan Minuman Lokal di Kota Semarang). Fakultas Ekonomi Universitas

Diponegoro.Semarang

Sahany. H.(2015).Pengaruh Pembiayaan Murabahah dan Mudharabah Terhadap
Perkembangan Usaha Mikro Kecil Menengah (UMKM) BMT EL Syifa Ciganjur.Jakarta

Sugiyono, (2006), Statistik Untuk Penelitian, Bandung : Alfabeta

Sugiyono, (2012), Metode Penelitian Kuantitatif, Kualitatif dan $R \& D$, Bandung: Alfabeta

Suparyono,Y.(1981).Konstruksi

Perspektif.Yogyakarta.Kanisius

Anggota (IKAPI)

Suryati.(2012).

Pengaruh

Pembiayaan Mudharabah

Terhadap Perkembangan Usaha dan Pendapatan Nasabah Mudharabah di Bmt Binamas Purworejo.Jurnal Pendidikan dan Ekonomi.JPE Edisi Volume I Nomor 2

Wibowo, A dan Sunarto(N.Y).Pengaruh pembiayaan mudharabah Dan musyarakah Terhadap Profitabilitas Perbankan syariah (Studi Kasus Padabank Pembiayaan Rakyat Syariah Daerah Istimewa Yogyakarta Yang Terdaftar Di Bank Indonesia Periode 2012-2014). Syariah Paper Accounting FEB UMS, ISSN 2460-0784 (online) url:

https://publikasiilmiah.ums.ac.i d/bitstream/handle/11617/7344/ $10 \% 20-$ 
\%20Arief\%20Wibowo.pdf?seque nce $=1$ di akses tanggal o8 September 2018 jam 12.00 wib Iska,S.(2012).Simtem Perbankan Syariah di Indonesia. Dalam Perspektif Fikih
Ekonomi.Yogyakarta.Fajar Media Press

Indonesia, B.I.(2014).Memahami Bisnis Bank Syariah.Jakarta. PT. Gremadia Pusaka Utama, Jakarta 